\begin{tabular}{lcl}
\hline Bentham open & The Open Chemical Engineering & $\substack{\text { The Open } \\
\text { Chemical Engineering } \\
\text { lournal }}$ \\
CrossMark & Content list available at: www.benthamopen.com/TOCENGJ/ & DOI: $10.2174 / 1874123101610010041$ \\
\hline
\end{tabular}

\title{
Solubility of Mixtures Containing Soybean Oil, Ionic Liquid and Methanol
}

\author{
Marina S. Manic and Vesna Najdanovic-Visak ${ }^{*}$ \\ Energy Lancaster, Engineering Department, Lancaster University, Lancaster LA1 4YR, United Kingdom
}

\begin{abstract}
This paper presents data on mutual solubility of the binary (soybean oil + ionic liquid) and ternary (soybean oil + methanol + ionic liquid) systems, where ionic liquid stands for 1-butyl-3-methylimidazolium thiocyanate [C4MIM][SCN] or 1-butyl-3-methylimidazolium bis(trifluoromethylsulfonyl)imide [C4MIM][NTf2] or 1-butyl-3-methylimidazolium dicyanamide [C4MIM][DCA] or 1-butyl-3-methylimidazolium hexafluorophosphate [C4MIM][PF6] or 1-butyl-3-methyl imida zolium hydrogensulfate [C4MIM] [HSO4] or 1-decyl-3-methylimidazolium bis(trifluoromethylsulfonyl)imide [C10MIM][NTf2] or methyltrioctylammonium bis(trifluoromethylsulfonyl)imide [ALIQUAT][NTf2] or methyltrioctylammonium chloride [ALIQUAT][Cl]. Solubilities were determined by the cloud point titration method in the temperature range of $298 \mathrm{~K}$ to $343 \mathrm{~K}$. Obtained results suggest that imidazolium based ionic liquids exhibit lower solubility in soybean oil than ionic liquids with the aliquat cation. Thus, aliquat based ionic liquids are good candidate to be used as co-solvents for biphasic (methanol + soybean oil) mixture.
\end{abstract}

Keywords: Biodiesel, Ionic liquids, Solubility soybean oil, Methanol.

\section{INTRODUCTION}

One of the main environmental problems of our time is the atmospheric accumulation of gases that causes the socalled greenhouse effect, due to the use of fossil fuels. Due to its excellent fuel properties, renewability and biodegradability, biodiesel present a possible alternative to fossil fuels. In the last decade, considerable quantity of research is being done about the use of vegetable or animal oils as feedstock for biodiesel production [1,2]. The most common way to produce biodiesel is through the transesterification of oils with an alcohol [3]. This yields fatty acid alkyl esters and glycerol. Methanol is the most commonly used alcohol, partly due to its low cost. The transesterification reaction can be catalyzed by alkaline and acidic catalysts, by enzymes [4] or can be carried out without added catalyst $[5,6]$. The most common sources of oil for biodiesel production are soybean oil due to the best quality end product. A soy oil based diesel fuel tends to have more efficient conversion rates and better flowability in cold temperatures compared to other oils and fats.

Beside the fact that room temperature ionic liquids (ILs) were initially introduced as alternative green reaction media because of their chemical and physical properties of nonvolatility, nonflammability, thermal stability, and controlled miscibility [7], today show their significant role in controlling the reaction as solvents and catalysts. By combining different cations and anions a variety of ionic liquids can be obtained with desired solvent properties [8]. Moreover, the incorporation of specific functional groups dramatically enhances solubility with specific solutes, such as polar substrates or catalysts [9]. Although ionic liquids have been successfully employed for many organic reactions, their using for the transesterification is scarcely addressed. Wu et al. [10] used functional Brønsted acidic ionic liquids as solvents and catalysts for transesterification of cottonseed oil opening potential of application in the biodiesel production. In addition, mixture of quaternary ammonium salts with glycerol has been used to extract glycerol from biodiesel formed from the reaction of triglycerides with ethanol in the presence of KOH [11].

\footnotetext{
* Address correspondence to this author at Energy Lancaster, Engineering Department, Lancaster University, Lancaster LA1 4YR, United Kingdom; Tel: +44 (0)1524 593 586, E-mail: v.najdanovic@lancaster.ac.uk
} 
In general, traditional transesterification is biphasic (methanol + oil phase) and reversible reaction and therefore knowledge on mutual solubility of reactants and products is a paramount for the design of related technological process.Moreover, it was shown that the transesterification reaction takes place in the methanol phase, thus the reaction rate greatly depends on the solubility of oil in methanol phase which is quite low [12]. Therefore, utilization of cosolvent is desirable in order to enhance the solubility of oil in the phase where reaction takes place (methanol-rich phase). To do so, most studies reported utilization of flammable and hazardous solvents such as tetrahydrofuran [13], petroleum ether [14] and hexane [15].

The aim of this study was to examine various ionic liquids as a cosolvent for components involved in biodiesel production. Thus, in this contribution mutual solubility of binary and ternary mixtures containing ionic liquid, soybean oil and methanol in the range of 298 to $343 \mathrm{~K}$ is reported, whereas ionic liquid stands for 1-butyl-3-methylimidazolium

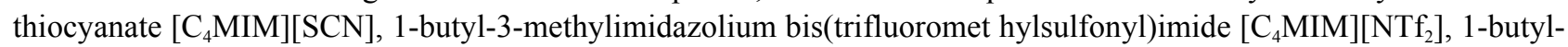

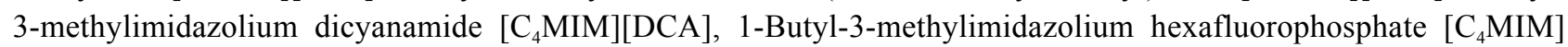
$\left[\mathrm{PF}_{6}\right]$, 1-butyl-3-methylzolium hydrogensulfate $\left[\mathrm{C}_{4} \mathrm{MIM}\right]\left[\mathrm{HSO}_{4}\right]$, 1-decyl-3-methylimidazolium bis(trifluoromethylsulfonyl)imide $\left[\mathrm{C}_{10} \mathrm{MIM}\right]\left[\mathrm{NTf}_{2}\right]$, methyltriocty lammonium bis(trifluoromethylsulfonyl) imide [ALIQUAT][NTf $\left.\mathrm{A}_{2}\right]$ and methyltrioctylammonium chloride [ALIQUAT][Cl].

\section{EXPERIMENTAL PROCEDURES}

\subsection{Chemicals}

All ionic liquids used in this study are commercial. Table 1 summaries ionic liquids full names, abbreviations, water contents, chemical structures, and their sources. To reduce the water content and volatile compounds to negligible values, vacuum $(0.1 \mathrm{~Pa})$ and moderate temperature $(333 \mathrm{~K})$ were applied to the IL samples for several days always immediately prior to their use.

Table 1. Ionic liquids used in this study.

\begin{tabular}{|c|c|c|c|c|}
\hline Chemical Name & Abbreviation & Structure & \begin{tabular}{|c|} 
Water \\
Content $/ /$ \\
ppm
\end{tabular} & Source \\
\hline 1-Butyl-3-methylimidazolium thiocyanate & {$\left[\mathrm{C}_{4} \mathrm{mim}\right][\mathrm{SCN}]$} & . & 70 & IoLiTec \\
\hline $\begin{array}{l}\text { 1-Butyl-3-methylimidazolium } \\
\text { bis(trifluoromethylsulfonyl)imide }\end{array}$ & {$\left[\mathrm{C}_{4} \mathrm{mim}\right]\left[\mathrm{NTf}_{2}\right]$} & & 60 & Solchemar \\
\hline 1-Butyl-3-methylimidazolium dicyanamide & {$\left[\mathrm{C}_{4} \operatorname{mim}\right][\mathrm{DCA}]$} & & 75 & IoLiTec \\
\hline $\begin{array}{l}\text { 1-Butyl-3-methylimidazolium } \\
\text { hexafluorophosphate }\end{array}$ & {$\left[\mathrm{C}_{4} \operatorname{mim}\right]\left[\mathrm{PF}_{6}\right]$} & & 90 & Solchemar \\
\hline 1-Butyl-3-methylimidazolium hydrogensulfate & {$\left[\mathrm{C}_{4} \mathrm{mim}\right]\left[\mathrm{HSO}_{4}\right]$} & & 125 & Sigma-Aldrich \\
\hline $\begin{array}{l}\text { 1-Decyl-3-methylimidazolium } \\
\text { bis(trifluoromethylsulfonyl)imide }\end{array}$ & {$\left[\mathrm{C}_{10} \mathrm{mim}\right]\left[\mathrm{NTf}_{2}\right]$} & & 80 & Solchemar \\
\hline $\begin{array}{c}\text { Methyltrioctylammonium } \\
\text { bis(trifluoromethylsulfonyl)imide }\end{array}$ & [ALIQUAT][NTf & & 100 & IoLiTec \\
\hline
\end{tabular}




\begin{tabular}{|c|c|c|c|c|}
\hline Chemical Name & Abbreviation & Structure & $\begin{array}{c}\text { Water } \\
\text { Content } / \\
\text { ppm }\end{array}$ & Source \\
\hline Methyltrioctylammonium chloride & [ALIQUAT][Cl] & & 95 & Sigma-Aldrich \\
\hline
\end{tabular}

The water content included in Table 1 was determined performing Karl-Fischer Coulometric titration (Metrohm 831 KF Coulometer). All liquid solutions were gravimetrically prepared to an estimated uncertainty of $0.02 \%$ for a typical non-diluted mass percentage.

Anhydrous methanol (purity 99.8 mass \%) was purchased from MERCK and was further dried with $3 \mathrm{~A}^{\circ}$ molecular sieves.

The soybean oil was received from Sigma-Aldrich. The crude soybean oil contains free fatty acids which can negatively affect eventual transesterification yields due to soap formation [16]. Therefore, in the conventional processes the acidification process is performed prior to transesterification. All samples of soybean oil used in this study were treated with $\mathrm{KOH}$ solution in the ratio oil to $5 \mathrm{M} \mathrm{KOH}$ in volume 1:16. Afterwards, this mixture was heated to $333 \mathrm{~K}$ and stir. After settling, the soap stock remained at the bottom. The deacidified oil was separated from the soap stock and dried over $\mathrm{Na}_{2} \mathrm{SO}_{4}$.

\subsection{Analysis of Acid Content}

The acid number is defined as mass of potassium hydroxide, in milligrams, used to neutralize free acids in one gram of sample oil. Approximately 2 grams of oil was weighted and then $25 \mathrm{~mL}$ of mixture of ethyl ether: ethyl alcohol (2:1 $\mathrm{v} / \mathrm{v}$ ) as well as two drops of phenolphthalein solution were added. This mixture was titrated with $0.05 \mathrm{M} \mathrm{KOH}$ solution until a solution changes its color from transparent to light rose. The acidic number $(A N)$ is calculated according to equation (1):

$$
A N=\frac{V \cdot C \cdot 56.1}{m}
$$

where $V$ is the volume of $\mathrm{KOH}$ solution used for titration in $\mathrm{mL}, C$ is a molar concentration of solution in $\mathrm{mol}\left(\mathrm{dm}^{-3}\right.$ and $m$ is the mass of oil sample in $\mathrm{g}$.

\subsection{Solubility Measurements}

Solubility curves were determined by the cloud point titration method in a magnetically stirred and temperaturecontrolled equilibrium cell [17]. Binary mixture of known composition was titrated with the third component at constant temperature. The transition point is taken as the appearance/disappearance of turbidity in the sample and it is defined as a cloud point. The liquid phase occupied almost whole volume of the cell in order to avoid corrections to composition due to vaporization.

All visual experiments were repeated at least two times in order to acquire higher accuracy. The temperature was controlled by means of a built-in temperature controller while it was also monitored with a thermometer. The estimated precisions of the cloud point temperature and mole fractions are $\pm 1 \mathrm{~K}$ and \pm 0.01 , respectively.

\section{RESULTS AND DISCUSSION}

The average molecular weight of soybean oil was adapted from our previous work [17]: $866.5 \mathrm{~g}\left(\mathrm{~mol}^{-1}\right.$. Even though the oil is a mixture of various triglycerides, we considered it as a single component. Acid number of the oil before and after deacidification is 0.95 and $0.04(\mathrm{mg} \mathrm{KOH}) /(1 \mathrm{~g}$ of oil $)$, respectively. The applied method sufficiently decreased the content of free fatty acids, making it suitable for conventional transesterification.

The cloud point data of ternary (methanol + soybean oil + ionic liquid) systems are presented in Table 2.

All ionic liquids used in this study showed complete miscibility with methanol in the whole range of concentrations and studied temperatures. On the contrary, with the exception of ALIQUAT Cl ionic liquid (completely soluble), all the other (ionic liquid + soybean oil) systems studied illustrated limited mutual solubility, which slightly increased as 
temperature raised. The mutual solubility of the binary (ionic liquid + soybean oil) systems at $298 \mathrm{~K}$ is presented in Fig. (1) as solubility of soybean oil in IL-rich phase (Fig. 1a) and solubility of ionic liquid in oil rich phase (Fig. 1b).

Thus, at $298 \mathrm{~K}$, the solubility of soybean oil in imidazolium ionic liquid rich phase goes from 0.16 to $1.36 \mathrm{~mol} \%$. A bit higher solubilities of these ionic liquids in soybean oil rich phase were witnessed, typically ranging from (2.2 to 4.1 mol) \% at $298 \mathrm{~K}$. In general, imidazolium based ionic liquids, independently of their counter anions, exhibit lower solubility in soybean oil than ionic liquids with the aliquat cation.

Comparing ionic liquids with the same cation, $\left[\mathrm{C}_{4} \mathrm{mim}^{+}\right]$, we can observe from (Fig. 1a) that the relative affinity of soybean oil to the various anions follows the order $\left.\left.\left.[\mathrm{SCN}]^{-}<\left[\mathrm{NTf}_{2}\right]^{-}<\mathrm{DCA}^{-}\right]<\mathrm{PF}_{6}\right]^{-}<\mathrm{HSO}_{4}\right]^{-}$. However, a different order of affinities was observed for the soybean oil-rich systems (Fig. 1b).

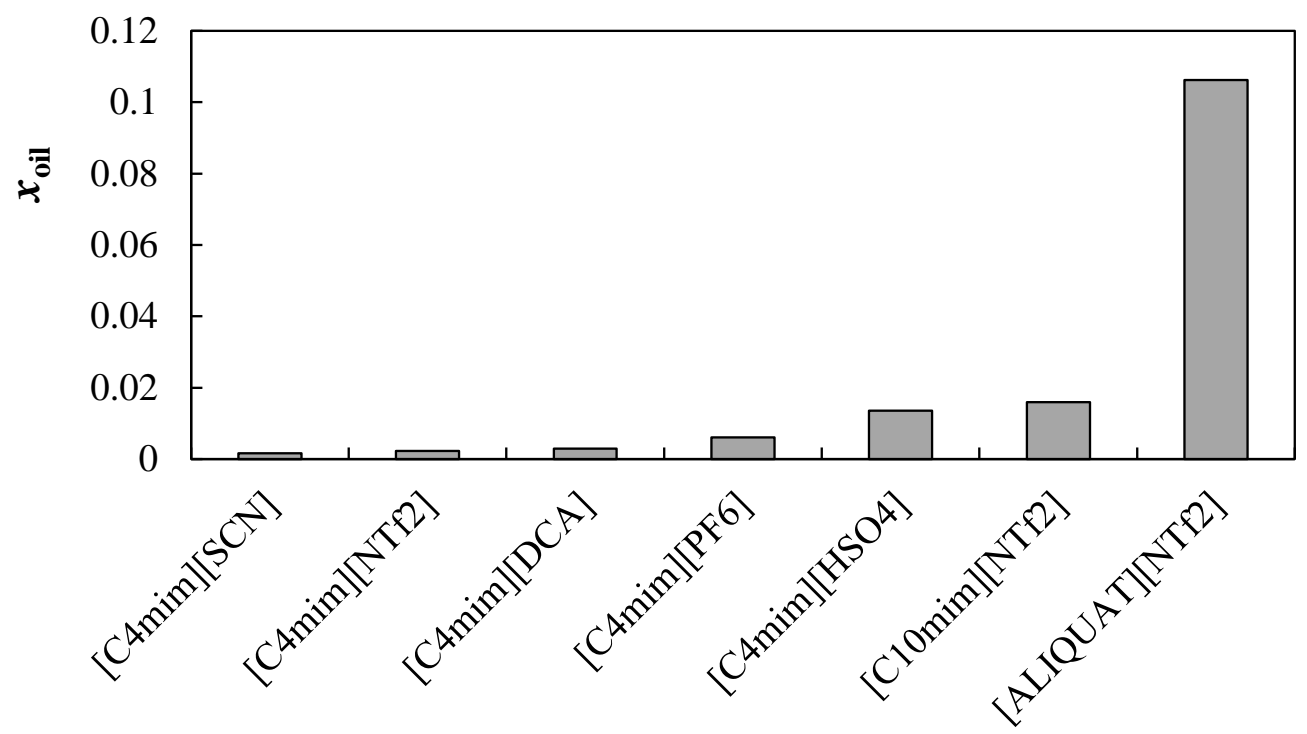

Ionic liquid

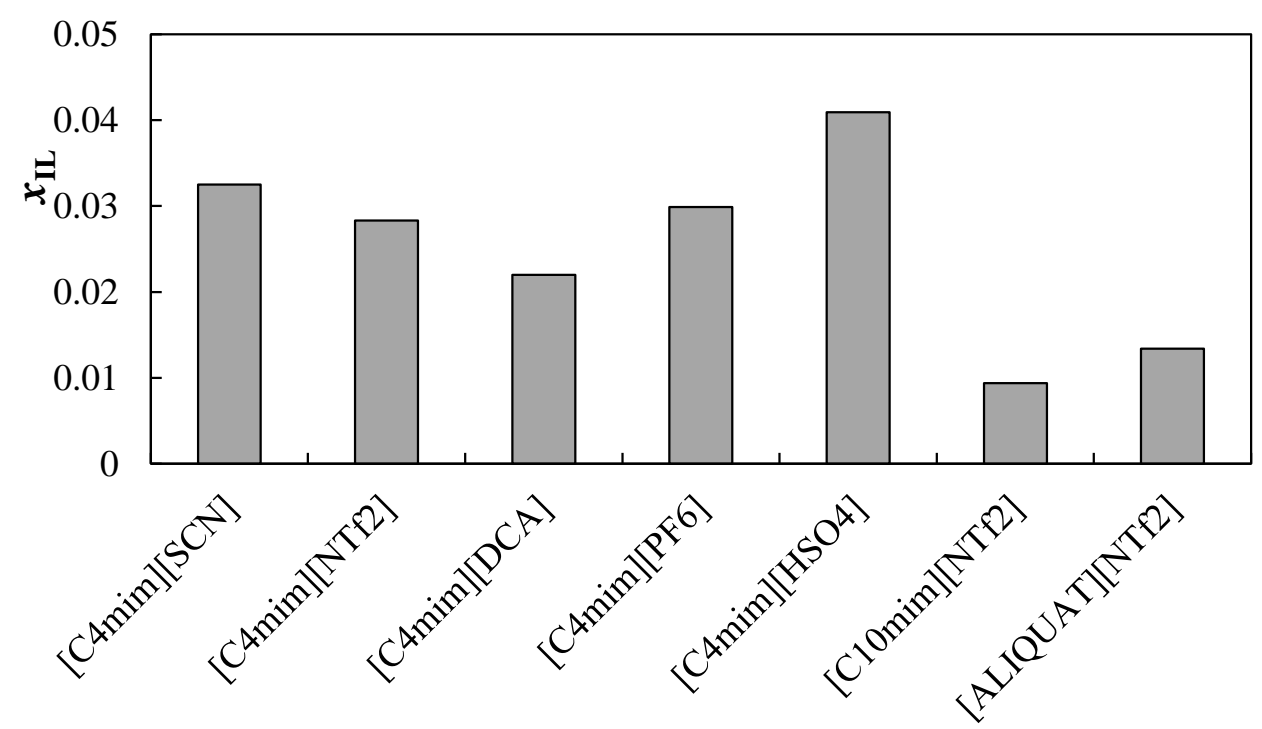

Ionic liquid

Fig. (1). Solubility of soybean oil in an ionic liquid (a) and solubility of ionic liquid in soybean oil (b) for various ionic liquids at 298 K. xoil and xIL stand for mole fraction of soybean oil in IL-rich phase and mole fraction of ionic liquid in soybean oil-rich phase, respectively. 
The longer alkyl chain in the imidazolium cation caused some what higher solubility of soybean in ionic liquids, ranging from $0.23 \mathrm{~mol} \%$ in the case of $\mathrm{C}_{4}$ mim $\mathrm{NTf}_{2}$ to $1.6 \mathrm{~mol} \%$ in the case of $\mathrm{C}_{10} \mathrm{mim} \mathrm{NTf}$. This is probably due to the fact that the van der Waals interactions increase between cation chain and the alkyl portion of the tryglicerides, similarly to ionic liquid behavior with alcohols [18].

In the case of the aliquat based ionic liquids, huge effect of anion on solubility was noticed. Thus, while aliquat $\mathrm{NTf}_{2}$ is slightly soluble with soybean oil, the system aliquat $[\mathrm{Cl}]+$ soybean oil is completely soluble.

The data reported in Table 2 were used to construct the ternary phase diagrams of the (methanol + soybean oil + IL) systems at atmospheric pressure (Fig. 2). The area inside envelopes corresponds to two phase region.

The huge area of mutual immiscibility (two-phase region) is observed for systems involving $\mathrm{C}_{4} \operatorname{mim}[\mathrm{SCN}], \mathrm{C}_{4} \mathrm{mim}$ $\mathrm{NTf}_{2}, \mathrm{C}_{4}$ mim DCA, $\mathrm{C}_{4}$ mim $\mathrm{PF}_{6}, \mathrm{C}_{4} \mathrm{mimHSO}_{4}$ and $\mathrm{C}_{10}$ mim $\mathrm{NTf}_{2}$. Somewhat better mutual miscibility was noted for ALIQUAT $\mathrm{NTf}_{2}$ and ALIQUAT[Cl] systems. As it can be concluded from Figs. (2f-h), increasing the temperature enhanced the mutual solubility.

Table 2. Phase equilibria data of ternary (methanol + soybean oil + ionic liquid) systems. All compositions are given in both mass (w) and mole fraction ( $x)$.

\begin{tabular}{|c|c|c|c|c|c|c|}
\hline Cation & Anion & $T / \mathbf{K}$ & $w \mathrm{MeOH}$ & woil & $x$ МеОН & xoil \\
\hline \multirow{4}{*}{ [C4mim] } & \multirow{4}{*}[\mathrm{SCN}]{} & \multirow{4}{*}{298} & 0 & 0.0069 & 0 & 0.0016 \\
\hline & & & 0 & 0.9924 & 0 & 0.9675 \\
\hline & & & 0.5044 & 0.0042 & 0.8632 & 0.0003 \\
\hline & & & 0.0033 & 0.9930 & 0.0812 & 0.9040 \\
\hline \multirow{4}{*}{ [C4mim] } & \multirow{4}{*}[\mathrm{NTf}_{2}]{} & \multirow{4}{*}{298} & 0 & 0.0047 & 0 & 0.0023 \\
\hline & & & 0 & 0.9861 & 0 & 0.9717 \\
\hline & & & 0.5140 & 0.0060 & 0.9331 & 0.0004 \\
\hline & & & 0.0032 & 0.9935 & 0.0796 & 0.9141 \\
\hline \multirow{4}{*}{ [C4mim] } & \multirow{4}{*}[\mathrm{DCA}]{} & \multirow{4}{*}{298} & 0 & 0.0125 & 0 & 0.0030 \\
\hline & & & 0 & 0.9947 & 0 & 0.9780 \\
\hline & & & 0.4862 & 0.0031 & 0.8591 & 0.0002 \\
\hline & & & 0.0019 & 0.9960 & 0.0486 & 0.9430 \\
\hline \multirow{3}{*}{ [C4mim] } & \multirow{3}{*}[\mathrm{PF}_{6}]{} & \multirow{3}{*}{298} & 0 & 0.0184 & 0 & 0.0061 \\
\hline & & & 0 & 0.9900 & 0 & 0.9701 \\
\hline & & & 0.4093 & 0.0167 & 0.8625 & 0.0013 \\
\hline \multirow{4}{*}{ [C4mim] } & \multirow{4}{*}[\mathrm{HSO}_{4}]{} & \multirow{4}{*}{298} & 0 & 0.0481 & 0 & 0.0136 \\
\hline & & & 0 & 0.9885 & 0 & 0.9591 \\
\hline & & & 0.4923 & 0.0030 & 0.8779 & 0.0002 \\
\hline & & & 0.0159 & 0.9711 & 0.2968 & 0.6703 \\
\hline \multirow{16}{*}{ [C10mim] } & \multirow{16}{*}[\mathrm{NTf}_{2}]{} & \multirow{8}{*}{298} & 0 & 0.0272 & 0 & 0.0160 \\
\hline & & & 0 & 0.9945 & 0 & 0.9906 \\
\hline & & & 0.2061 & 0.0139 & 0.8045 & 0.0020 \\
\hline & & & 0.0014 & 0.9939 & 0.0364 & 0.9558 \\
\hline & & & 0.4999 & 0.0058 & 0.9405 & 0.0004 \\
\hline & & & 0.0033 & 0.9934 & 0.0820 & 0.9128 \\
\hline & & & 0.8100 & 0.0089 & 0.9856 & 0.0004 \\
\hline & & & 0.0065 & 0.9920 & 0.1502 & 0.8476 \\
\hline & & \multirow{8}{*}{343} & 0 & 0.0324 & 0 & 0.0191 \\
\hline & & & 0 & 0.9942 & 0 & 0.9901 \\
\hline & & & 0.2048 & 0.0200 & 0.8038 & 0.0029 \\
\hline & & & 0.0018 & 0.9921 & 0.0463 & 0.9437 \\
\hline & & & 0.4992 & 0.0072 & 0.9404 & 0.0005 \\
\hline & & & 0.0050 & 0.9900 & 0.1193 & 0.8731 \\
\hline & & & 0.8090 & 0.0089 & 0.9855 & 0.0004 \\
\hline & & & 0.0124 & 0.9848 & 0.2531 & 0.7433 \\
\hline
\end{tabular}




\begin{tabular}{|c|c|c|c|c|c|c|}
\hline Cation & Anion & $T / \mathrm{K}$ & $w \mathrm{MeOH}$ & woil & $x \mathrm{MeOH}$ & xoil \\
\hline \multirow{24}{*}{ [ALIQUAT] } & \multirow{24}{*}[\mathrm{NTf}_{2}]{} & \multirow{8}{*}{298} & 0 & 0.1369 & 0 & 0.1062 \\
\hline & & & 0 & 0.9899 & 0 & 0.9866 \\
\hline & & & 0.4883 & 0.0236 & 0.9514 & 0.0017 \\
\hline & & & 0.0151 & 0.9713 & 0.2921 & 0.6949 \\
\hline & & & 0.1842 & 0.0787 & 0.8243 & 0.0130 \\
\hline & & & 0.0021 & 0.9892 & 0.0537 & 0.9353 \\
\hline & & & 0.7879 & 0.0065 & 0.9870 & 0.0003 \\
\hline & & & 0.0418 & 0.9472 & 0.5409 & 0.4521 \\
\hline & & \multirow{8}{*}{323} & 0 & 0.1673 & 0 & 0.1308 \\
\hline & & & 0 & 0.9860 & 0 & 0.9814 \\
\hline & & & 0.4729 & 0.0553 & 0.9492 & 0.0041 \\
\hline & & & 0.0170 & 0.9676 & 0.3175 & 0.6683 \\
\hline & & & 0.1788 & 0.1062 & 0.8202 & 0.0180 \\
\hline & & & 0.0039 & 0.9799 & 0.0953 & 0.8851 \\
\hline & & & 0.7727 & 0.0255 & 0.9861 & 0.0012 \\
\hline & & & 0.0379 & 0.9523 & 0.5150 & 0.4784 \\
\hline & & \multirow{8}{*}{343} & 0 & 0.1977 & 0 & 0.1558 \\
\hline & & & 0 & 0.9782 & 0 & 0.9711 \\
\hline & & & 0.4592 & 0.0827 & 0.9471 & 0.0063 \\
\hline & & & 0.0190 & 0.9639 & 0.3424 & 0.6424 \\
\hline & & & 0.1716 & 0.1415 & 0.8144 & 0.0248 \\
\hline & & & 0.0049 & 0.9749 & 0.1168 & 0.8594 \\
\hline & & & 0.7645 & 0.0357 & 0.9856 & 0.0017 \\
\hline & & & 0.0427 & 0.9463 & 0.5458 & 0.4472 \\
\hline \multirow{22}{*}{ [ALIQUAT] } & \multirow{22}{*}[\mathrm{Cl}]{} & \multirow{9}{*}{298} & 0.1420 & 0.3927 & 0.7345 & 0.0750 \\
\hline & & & 0.0526 & 0.7120 & 0.5391 & 0.2697 \\
\hline & & & 0.2560 & 0.2369 & 0.8396 & 0.0287 \\
\hline & & & 0.0474 & 0.8327 & 0.5411 & 0.3507 \\
\hline & & & 0.5481 & 0.0614 & 0.9429 & 0.0039 \\
\hline & & & 0.0490 & 0.9160 & 0.5722 & 0.3954 \\
\hline & & & 0.8686 & 0.0071 & 0.9885 & 0.0003 \\
\hline & & & 0.0739 & 0.6085 & 0.6082 & 0.1849 \\
\hline & & & 0.4069 & 0.1227 & 0.9069 & 0.0101 \\
\hline & & \multirow{7}{*}{323} & 0.1445 & 0.4188 & 0.7428 & 0.0795 \\
\hline & & & 0.0778 & 0.6870 & 0.6388 & 0.2083 \\
\hline & & & 0.4274 & 0.1078 & 0.9129 & 0.0085 \\
\hline & & & 0.8051 & 0.0200 & 0.9822 & 0.0009 \\
\hline & & & 0.0523 & 0.9356 & 0.5958 & 0.3933 \\
\hline & & & 0.0558 & 0.8518 & 0.5902 & 0.3325 \\
\hline & & & 0.2929 & 0.1910 & 0.8594 & 0.0207 \\
\hline & & \multirow{6}{*}{343} & 0.7967 & 0.0198 & 0.9812 & 0.0009 \\
\hline & & & 0.1143 & 0.6549 & 0.7291 & 0.1543 \\
\hline & & & 0.1846 & 0.4088 & 0.7961 & 0.0651 \\
\hline & & & 0.6166 & 0.0437 & 0.9558 & 0.0025 \\
\hline & & & 0.3495 & 0.1998 & 0.8903 & 0.0188 \\
\hline & & & 0.2687 & 0.2673 & 0.8522 & 0.0313 \\
\hline
\end{tabular}

An excess of alcohol is used in biodiesel production to ensure the maximal yield. The optimal molar ratio of alcohol to triglycerides in most reports is 6:1 [2]. This corresponds to molar ratio of methanol in soybean 0.86 which is a binary mixture exhibiting two-phase system. It is clear from Figs. (2g, h) that both aliquat based ionic liquids can be used as cosolvents to solubilize binary (methanol + soybean oil) mixture. 

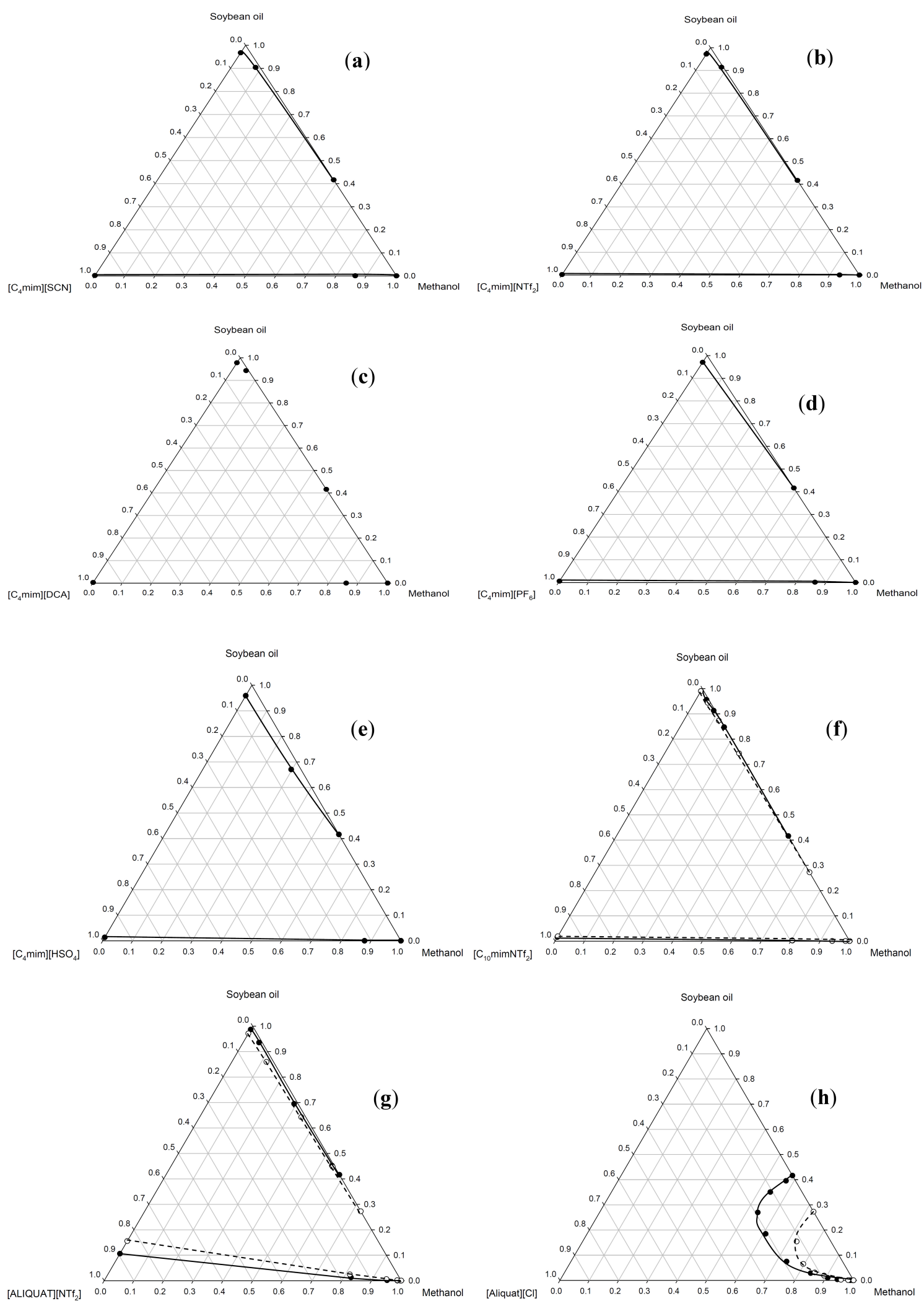

[ALIQUAT][NTE

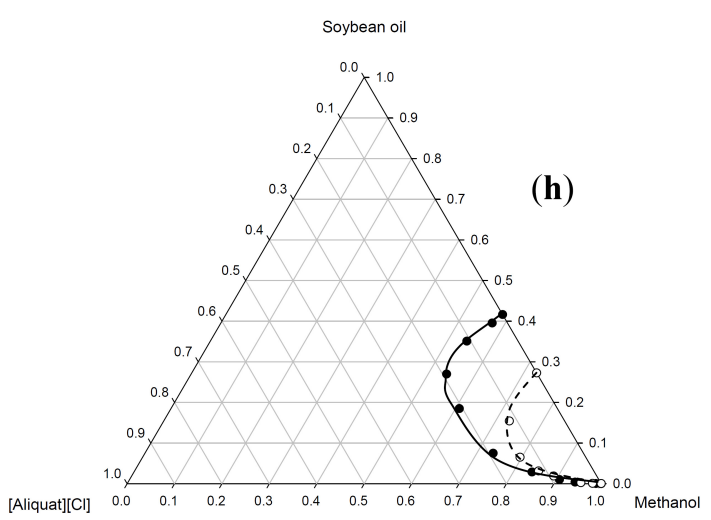

Fig. (2). Ternary diagrams for ternary methanol + soybean oil + ionic liquid at atmospheric pressure (compositions are given in mole fractions). Ionic liquid stands for $[\mathrm{C} 4 \mathrm{mim}][\mathrm{SCN}](\mathbf{a}),\left[\mathrm{C}_{4} \mathrm{mim}\right]\left[\mathrm{NTf}_{2}\right](\mathbf{b}),[\mathrm{C} 4 \mathrm{mim}][\mathrm{DCA}](\mathbf{c}),\left[\mathrm{C}_{4} \mathrm{mim}\right]\left[\mathrm{PF}_{6}\right](\mathbf{d}),\left[\mathrm{C}_{4} \mathrm{mim}\right]\left[\mathrm{HSO}_{4}\right](\mathbf{e})$, $\left[\mathrm{C}_{10} \mathrm{mim}\right]\left[\mathrm{NTf}_{2}\right](\mathbf{f}),[\mathrm{ALIQUAT}]\left[\mathrm{NTf}_{2}\right](\mathbf{g})$, and [ALIQUAT] $[\mathrm{Cl}](\mathbf{h})$. The full lines and filled circles correspond to data at $298 \mathrm{~K}$, while dashed lines and empty circles correspond to data at $343 \mathrm{~K}$. 


\section{CONCLUSION}

Data on mutual solubility of binary (soybean oil + ionic liquid) and ternary (soybean oil + methanol + ionic liquid) systems in the temperature range of $298 \mathrm{~K}$ to $343 \mathrm{~K}$ were reported. The following conclusions were made: 1) imidazolium based ionic liquids lower solubility in soybean oil than ionic liquids with the aliquat cation; 2) the solubility is enhanced by the longer alkyl chain in the imidazolium cation and by temperature increase; 3 ) aliquat based ionic liquids are good candidate to be used as cosolvents for biphasic (methanol + soybean oil) mixture.

\section{CONFLICT OF INTEREST}

The authors confirm that this article content has no conflict of interest.

\section{ACKNOWLEDGEMENTS}

Declared none.

\section{REFERENCES}

[1] F. Ma, and M.A. Hanna, "Biodiesel production: a review", Bioresour. Technol., vol. 70, pp. 1-15, 1999. [http://dx.doi.org/10.1016/S0960-8524(99)00025-5]

[2] D.Y. Leung, X. Wu, and M.K. Leung, "A review on biodiesel production using catalyzed transesterification", Appl. Energy, vol. 87, pp. 1083-1095, 2010.

[http://dx.doi.org/10.1016/j.apenergy.2009.10.006]

[3] A. Demirbas, "Comparison of transesterification methods for production of biodiesel from vegetable oils and fats", Energy Convers. Manage., vol. 49, pp. 125-130, 2008. [http://dx.doi.org/10.1016/j.enconman.2007.05.002]

[4] V. Rathore, and G. Madras, "Synthesis of biodiesel from edible and non-edible oils in supercritical alcohols and enzymatic synthesis in supercritical carbon dioxide", Fuel, vol. 86, pp. 2650-2659, 2007. [http://dx.doi.org/10.1016/j.fuel.2007.03.014]

[5] D. Kusdiana, and S. Saka, "Effects of water on biodiesel fuel production by supercritical methanol treatment", Bioresour. Technol., vol. 91, no. 3, pp. 289-295, 2004.

[http://dx.doi.org/10.1016/S0960-8524(03)00201-3] [PMID: 14607489]

[6] F. Calixto, J. Fernandes, R. Couto, E.J. Hernández, V. Najdanovic-Visak, and P.C. Simões, "Synthesis of fatty acid methyl estersvia direct transesterification with methanol/carbon dioxide mixtures from spent coffee grounds feedstock", Green Chem., vol. 13, pp. 1196-1202, 2011. [http://dx.doi.org/10.1039/c1gc15101k]

[7] V. Najdanovic-Visak, J.M. Esperanca, L.P. Rebelo, M. Nunes da Ponte, H.J. Guedes, K.R. Seddon, H.C. de Sousa, and J. Szydlowski, "Pressure, isotope, and water co-solvent effects in liquid-liquid equilibria of (ionic liquid plus alcohol) systems", J. Phys. Chem. B, vol. 107, pp. 12797-12807, 2003 [http://dx.doi.org/10.1021/jp034576x]

[8] N.V. Plechkova, and K.R. Seddon, "Applications of ionic liquids in the chemical industry", Chem. Soc. Rev., vol. 37, no. 1, pp. 123-150, 2008.

[http://dx.doi.org/10.1039/B006677J] [PMID: 18197338]

[9] V. Najdanovic-Visak, A. Rodriguez, Z.P. Visak, J.N. Rosa, C.A. Afonso, M. Nunes da Ponte, and L.P. Rebelo, "Co-solvent effects in LLE of 1-hydroxyethyl-3-methylimidazolium based ionic liquids plus 2-propanol plus dichloromethane or 1,2-dichloroethane", Fluid Phase Equilib., vol. 254 , pp. 35-41, 2007. [http://dx.doi.org/10.1016/j.fluid.2007.02.020]

[10] Q. Win, H. Chen, M. Han, D. Wang, and J. Wang, "Transesterification of cottonseed oil catalyzed by brønsted acidic ionic liquids", Ind. Eng. Chem. Res., vol. 46, pp. 7955-7960, 2007.

[http://dx.doi.org/10.1021/ie070678o]

[11] A.P. Abbott, P.M. Cullis, M.J. Gibson, R.C. Harris, and E. Raven, "Extraction of glycerol from biodiesel into a eutectic based ionic liquid", Green Chem., vol. 9, pp. 868-872, 2007. [http://dx.doi.org/10.1039/b702833d]

[12] H. Zhou, H. Lu, and B. Liang, "Solubility of multicomponent systems in the biodiesel production by transesterification of jatropha curcas 1. oil with methanol", J. Chem. Eng. Data, vol. 51, pp. 1130-1135, 2006. [http://dx.doi.org/10.1021/je0600294]

[13] R. Sawangkeaw, K. Bunyakiat, and S. Ngamprasertsith, "Effect of co-solvents on production of biodiesel via transesterification in supercritical methanol", Green Chem., vol. 9, pp. 679-685, 2007. [http://dx.doi.org/10.1039/b614064e]

[14] J. Qian, F. Wang, S. Liu, and Z. Yun, "In situ alkaline transesterification of cottonseed oil for production of biodiesel and nontoxic cottonseed meal", Bioresour. Technol., vol. 99, no. 18, pp. 9009-9012, 2008. 
[http://dx.doi.org/10.1016/j.biortech.2008.04.059] [PMID: 18571400]

[15] D. Nursanti, P. Religia, and A. Wijanarko, "Utilization of n-hexane as co-solvent to increase biodiesel yield on direct transesterification reaction from marine microalgae", Procedia Environ. Sci., vol. 23, pp. 412-420, 2015 [http://dx.doi.org/10.1016/j.proenv.2015.01.059]

[16] M. Balat, "Production of biodiesel from vegetable oils: a survey", Sources Part A, vol. 29, pp. 895-913, 2007. [http://dx.doi.org/10.1080/00908310500283359]

[17] M.S. Manic, V. Najdanovic-Visak, M. Nunes da Ponte, and Z.P. Visak, "Extraction of free fatty acids from soybean oil using ionic liquids or poly(ethyleneglycol)s", AIChE J., vol. 57, pp. 1344-1355, 2011.

[http://dx.doi.org/10.1002/aic.12349]

[18] J.M. Crosthwaite, A.N. Sudhir, E.J. Maginn, and J.F. Brennecke, "Liquid phase behavior of imidazolium-based ionic liquids with alcohols", J. Phys. Chem. B, vol. 108, pp. 5113-5119, 2004. [http://dx.doi.org/10.1021/jp037774x]

Received: September 17, 2015

Revised: December 17, 2015

Accepted: December 23, 2015

(C) Manic and Najdanovic-Visak; Licensee Bentham Open.

This is an open access article licensed under the terms of the Creative Commons Attribution-Non-Commercial 4.0 International Public License (CC BY-NC 4.0) (https://creativecommons.org/licenses/by-nc/4.0/legalcode), which permits unrestricted, non-commercial use, distribution and reproduction in any medium, provided the work is properly cited. 